\title{
Parents and Child Labour: A Testimony from Automobile Workshops in Islamabad
}

\author{
Muhammad Aboul Hassan Rashid*, Saif-ur-Rehman Saif Abbasi, Shahzad Farid, \\ Malik Maliha Manzoor \\ Department of Sociology, International Islamic University, Islamabad, Pakistan \\ Email: ${ }^{\text {aboulhassan87@yahoo.com }}$
}

Received 21 June 2015; accepted 23 August 2015; published 26 August 2015

Copyright (C) 2015 by authors and Scientific Research Publishing Inc.

This work is licensed under the Creative Commons Attribution International License (CC BY). http://creativecommons.org/licenses/by/4.0/

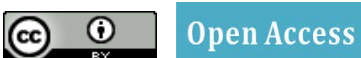

\begin{abstract}
The present study was aimed to find out some measures of child labour in the capital of Pakistan (Islamabad). Study explored some parental factors like (socio-economic status, criminal tendency of parents, their physical health, parental pressure, age of the parents as well as social acceptance of the parents) related to child labour. Child labor was one of the oldest curses that still refused to fade away in our part of the world. The main objective of the study was to determine the characteristics of working children in automobile workshops and to bring out those associated factors leading to child labor in automobile workshops in Islamabad. For the said purpose, 250 working children were then purposively drawn and attributed with less than 18 years of age in the locality of Islamabad. The information was obtained from the respondents by using interview schedule as a tool for the present study. Children were facing many problems at work such as cuts and burns $(48 \%)$, muscles pain $(28 \%)$, eyes infection and different orthopedic injuries $(10 \%)$ and $(14 \%)$ respectively. Results showed that a negative correlation existed between the variables (child labour and socio-economic status, physical health of parents) while all other variables such as age of the parents, social acceptance, criminal tendency and parental pressures were positively correlated with the measure (child labour).
\end{abstract}

\section{Keywords}

Child Labour, Parents, Islamabad, Automobile Workshops

\section{Introduction}

Many studies have been conducted across the countries on child labour, and generally define child labour as the

${ }^{*}$ Corresponding author.

How to cite this paper: Rashid, M. A. H., Abbasi, S., Farid, S., \& Manzoor, M. M. (2015). Parents and Child Labour: A Testimony from Automobile Workshops in Islamabad. Advances in Applied Sociology, 5, 234-241.

http://dx.doi.org/10.4236/aasoci.2015.58022 
economically active population. Recorded ages in all these studies are 10 - 14 year, because economic activity rates for the 10 - 14 population are available from the ILO and UN statistical databases. Examples of papers defining child labour as economically active population include: Becchetti \& Trovato (2005), Dehejia \& Gatti (2005), Edmonds \& Pavcnik (2005), Neumayer \& De Soysa (2005), Cigno et al. (2002), Shelburne (2001), Hussain \& Maskus (2003).

In the Basu and Van model, child labour is effectively undefined. The child is either a child labourer or the child is not. The modeling assumption is that a child participates in child labour to help the family to meet their subsistence needs and stops when the family's adult only earnings are sufficiently high so that subsistence is met without the child's contribution. This approach to child labour appears in other studies by Basu (Basu 1999, 2002, 2005) as well as Genicot (2005) and Rogers \& Swinnerton (2004) who employ a similar approach in considering child participation in exploitative work.

Working children have many problems and serious threats related to their work. Many studies attempt to assess the injury and morbidity risks associated with the child's work environment. Graitcer \& Lerer (1998) list morbidity, injury, and hazard risks faced by children in different occupations and industries. Working environment effects just not health of children but it has harmful collision on their personality development. Parker (1997) emphasizes that children who start work at a young age will be exposed to environmental hazards in the work place for longer, perhaps at a time when the effects of these hazards on development are more substantive. Beyond the direct risks of work, the increased nutritional needs associated with grueling work may aggravate malnutrition, the increased nutritional needs associated with grueling work and aggravate malnutrition and impairing the child's productivity into adulthood.

and impairing the child's productivity into adulthood (Forastieri, 2002).

There is a debate over the interpretation of this evidence, because there is a strong correlation between severe stress in childhood and stressful life events in adulthood (Horowitz et al., 2001). Some researches argue that this association reflects that childhood trauma induces a vulnerability to the effects of stress later in life. Most of these researches focused on stresses like the loss of a parent and severe physical abuse at very young ages, so whether this evidence is relevant for typical working, child is an open question.

Many studies address that problem like economic variability can be the reason of child labour. These studies concentrate on the problem by relating child labour to variation in income that excludes the child's income (Dammert, 2005; Ray, 2000). Other studies argue that certain factors affect family income without also affecting the time allocation of children except through family income. Examples include Bhalotra (2007), Bhalotra \& Heady (2003), and Ersado (2005). Note that the assumptions required for identification are often quite strong in these studies, as almost anything that affects the family's economic environment should also influence the value of child time in one activity (schooling, work outside the home, market work in the home, domestic chores).

In South Asia child domestic labour, agriculture, debt bondage, hazardous and export industries, child trafficking, and informal sector are some common platforms for child labour. About 7.2\% of South Asian children between 5 to 14 years are labourers. On the basis of officially available statistics, it is estimated that in South Asia out of a total of 300 million children, aged between 5 to 14 years, 21.6 million children are labourers. In Bangladesh, out of 35.06 million children (5 - 14 years), 5.05 million children are working. Similarly in India, Nepal, Pakistan, and Sri Lanka, out of 210, 6.23, 40, and 3.18 million children, 11.2, 1.66, 3.3 and 0.48 million children are working respectively (Naseem, 2009).

Pakistan is one of those countries where the commonness of child labour is very high. A momentous number of children partake in economic activities and contribute substantially to household income in Pakistan. The National Child Labour Survey, conducted in 1996 by the Federal Bureau of Statistics (FBS), found 3.3 million out of the 40 million children (in the 5 - 14 years age group) to be economically active on a full-time basis. Out of 3.3 million working children, 1.94 million children between the age of 5 - 14 were active in the Punjab, 0.3 million in Sindh, 1.06 million in North West Frontier Province (NWFP) and 0.01 million in the Baluchistan (Kulsoom, 2009).

UNICEF (2000) stated that child labour is a serious and contentious issue throughout the developing world as it is destroying and damaging to a child's health and intellectual development. However, what counts as child labour and who counts as a worker is still a controversial issue and many jobs fall outside the law. Child labour continues to be a problem whose meaning shifts with social, geographical, economic and cultural context. In some regions child labour has persisted or reconstituted from the customary into the exploitative. Low wages, 
irregular hours of employment, exploitative slavery, atrocious working conditions, and lack of contracting power all characterize child labour in many countries. Generalization is elusive because there are significant variations among the different kinds of work done, which can range from family help for parents to industrial work.

Bibi (1980) revealed that parents of all the children employed as wage earner were illiterate. Majority of the parents sent their children to work due to their poor economic conditions. Thousands of children under the age of 15 years were working under highly unhygienic conditions. They were low paid and had to work for 60 to 90 hours a week.

In the city of Peshawar, there are hundreds of motor vehicle repair workshops, where huge numbers of children work without any safety measures. A considerable number of children work in these workshops out of financial necessity because of the low socioeconomic status of their families (Zakir et al., 2002).

Many econometric studies, using data from national or provincial household surveys, have examined the relationships between the incidence of children's work and various independent variables such as per capita or household incomes, children's school enrolment or attendance rates, parental education levels, national educational and other social policy measures and so on (for example, Awoniyi \& Oluwatayo, 2008; Edmonds \& Pavcnik, 2005; Gonza'lez-Vega \& Maldonado, 2008; Hadi \& Nath, 2000).

Pakistan is suffering from extremely tender socio-economic and political chaos. There are many reasons why share of child labor is increasing such as poverty, large family sizes, social attitudes and low literacy rate, worst economic crises, symmetry of natural disasters; devastation of infrastructure due to country-wide floods, earthquake, and large increase of unemployment (Human Rights Report, 2010; Bhalotra, 2007; Ahmed, 1991).

Awan et al. (2011) argued that the factors are absence of education of the mother, household heads education, large family size, low level of family income and less education of child pushed children into work that often damage to their development. Results have shown that low level income of the family drives children into hazardous labour. The parents of child labourers are mostly unemployed or underemployed, desperate for secure employment and income.

\section{Materials and Methods}

In the study, we randomly selected 250 available respondents who were working on different auto mobile workshops in Islamabad city. We used a structured interview guide to measure the demographic variables of working children and their parental (father(s)) related dimensions which are associated with child labour. Before collecting the data, ten interview schedules (Appendix 1) were pre-tested. Some minor modifications were made to match with the objectives of study. Data was analyzed by using SPSS (version 20). Descriptive analysis (percentage and frequencies) of demographic variables and problems at work were made while inferential statistical orientation was done by applying correlation analysis.

\section{Results and Discussions}

Table 1 shows that $60 \%$ of the working children were between 12 - 14 years of age; followed by $24 \%$ aged 15 17 years and 16\% were in the youngest age category of $8-11$ years. The mean age came to be 14 year. Table 1 depicts that most of respondents have got a little exposure of education and that is primary education level group is $14.4 \%$ of the whole. Second group presents a horrible picture as $79.2 \%$ our respondents have no educational experience. Most of the children have responsibilities to support their families because they have the large family size and being the eldest among their siblings they are considered to be responsible to fulfill the financial requirements of their families. Data shows that $51.2 \%$ of the respondents have large family size and most of them the eldest according to their birth order. $40 \%$ of the children had family member consist of 7 to 9 members which is also a large family size and seems difficult to manage this situation with low income. Family size can be of the important demographic factor that leads towards the triggering ratio of child labour in study area along with the low level of education and birth order. Their birth order can determine that their reason of working is their being eldest one and they are considered to be responsible for economic management of their families and to share the economic burden of their families as well.

Table 2 shows that $48 \%$ of the respondents faced cuts and burns during work, whereas $28 \%$ of them observed muscle pain due to working and, $14 \%$ and $10 \%$ of the respondents faced eyes and orthopedic injuries respectively.

Table 3 depicts the correlates of child labor. The table signified that the correlation of child labor with so- 
Table 1. Distribution of respondents with regard to their demographic profile.

\begin{tabular}{|c|c|c|c|}
\hline Variable & & Frequency & Percent \\
\hline \multirow{3}{*}{ Age } & 8 - 11 years & 40 & $16.0 \%$ \\
\hline & 12 - 14 years & 150 & $60.0 \%$ \\
\hline & 15 - 17 years & 60 & $24.0 \%$ \\
\hline \multirow{4}{*}{ Level of education } & 1 - 5 class & 36 & $14.4 \%$ \\
\hline & 6 - 8 class & 10 & $4.0 \%$ \\
\hline & 9 - 10 class & 6 & $2.4 \%$ \\
\hline & Illiterate & 198 & $79.2 \%$ \\
\hline \multirow{3}{*}{ Family size } & 4 - 6 members & 22 & $8.8 \%$ \\
\hline & 7 - 9 members & 100 & $40.0 \%$ \\
\hline & 10 - 12 members & 128 & $51.2 \%$ \\
\hline \multirow{4}{*}{ Birth Order } & Eldest & 109 & $43.6 \%$ \\
\hline & Second & 72 & $28.8 \%$ \\
\hline & Third & 43 & $17.2 \%$ \\
\hline & Youngest & 26 & $10.4 \%$ \\
\hline
\end{tabular}

Table 2. Distribution of respondents with regard to the problems faced during work.

\begin{tabular}{ccc}
\hline Problems faced & Frequency & Percent \\
\hline Cuts \& burn & 120 & $48.0 \%$ \\
Muscle pains & 70 & $28.0 \%$ \\
Eyes infection & 35 & $14.0 \%$ \\
Orthopedic injuries & 25 & $10.0 \%$ \\
\hline
\end{tabular}

Table 3. Correlates of child labour.

\begin{tabular}{cccccc}
\hline Socioeconomic Status & Age & Physical health & Social acceptance & Parental pressure & Criminal tendency \\
\hline-0.312 & 0.019 & -0.431 & 0.208 & 0.029 \\
0.000 & 0.000 & 0.000 & 0.000 & 0.000 & 0.000 \\
\hline
\end{tabular}

cioeconomic status $\mathrm{M}=66.59, \mathrm{SD}=12.5, r=-0.312$. Whereas, child labor has significant positive correlation with age $\mathrm{M}=56.92$, $\mathrm{SD}=13.946 r=0.019$. Physical health with these values of mean, standard deviation and correlation respectively, $\mathrm{M}=60.0, \mathrm{SD}=0.595, r=-0.432$ is significantly negative $(p<0.05)$ and social acceptance $\mathrm{M}=11.32$, $\mathrm{SD}=3.966, r=-0.028$. Parental pressure is positively correlated with child labour such as results demonstrate $\mathrm{M}=23.1, \mathrm{SD}=2.34, r=0.029$, while criminal tendency of parents was found as $\mathrm{M}=2.18$, $\mathrm{SD}=0.786, r=0.403$. The results revealed that socioeconomic status, physical health as well as criminal tendency of parents are most significant determinants of child labor in study area.

\section{Discussion}

Present study focused some important aspects related to the child labour. The working conditions were found to be hazardous and children were not given any safety measures during the work. The situation of working milieu is not protective and they (children) even do not know about the safety and precautionary measures to protect themselves from such cuts and burns and other physical injuries.

Findings of the study reveal some important parameters of child labour associated with parents of working children. Socio-economic status of families and especially household income can either reduce child labour by its own well-off or it can trigger this social evil in a negative way because of its own turn down. In the study of Mahmood et al. (2005) has been concise that the socioeconomic factors perpetuate the child labour. The case of automobile and engineering, according to them, the majority of the respondents were forced by their parents to 
work due to financial circumstances. It was further observed that poverty is the major responsible factor for child labour chased by few other reasons like lack of the interest in education, big family sizes and compulsive societal behaviour. It can be stated that some time parents send their children by them to work. They (parents) wanted their economic burden to be shared and for that very reason their children are working unwillingly.

Old age of fathers is another important factor which can give rise to the children to do work and to support their families. Weak physical and mental health of father(s) is also associated with their age, after losing their physical vigour they cannot carry out the economic burden of their families and usually the elder son is considered to be responsible to be a substitute of his father. There are several circumstances that affect child labour. Studies have demonstrated that the most notable reason being poverty (Bhat \& Rather, 2009). Decisions about child labour and schooling are generally made by parents. If the family live below the poverty line, parents see children as part of contributor in their family income. Basu (1998) used a theoretical model of child labour, where he showed the only reason parents send children to labour is because of their low income.

A growing number of children who have either lost one or both the parents and those impacted by hepatitis and cancer in the family, are forced to work in order to support themselves and their siblings. Health of parents and especially the father's health is a significant determinant of child labour in study area. This study has provided a significant insight into the link between parental socio-economic status and child labour. These findings are relevantly contradistinctive to the findings of Osiruemu (2007) which also found a significant relationship between poverty of parents and child labour. Such an outcome as this is not unlikely in a socio-economic environment with high negative economic indices.

\section{Conclusion}

The study has an important dimension (parental characteristics) related to the child labour at automobile workshops in Islamabad. It cannot be denied that poor economic condition, illiteracy, old age, involvement and intentions of criminal activities of parents of working child can foster child labour. A main attention is required to the parents than policies and practices should highlight the children directly because most of the children are working without their will and they are forced to do work because of their families' poor economic condition, absence of father and separation of parents as well.

\section{References}

Awan, M. S., Waqas, M., \& Aslam, M. A. (2011). Why Do Parents Make Their Children Work? Evidence from Multiple Indicator Cluster Survey. International Journal of Academic Research, 3, 545-549.

Basu, K., \& Van, P. H. (1998). The Economics of Child Labor. American Economic Review, 88, 412-427.

Basu, K. (1999). Child Labour: Cause, Consequence, and Cure, with Remarks on International Labour Standards. International Journal of Economic Literature, 37, 1083-1119. http://dx.doi.org/10.1257/jel.37.3.1083

Basu, K. (2002). A Note on the Multiple General Equilibria with Child Labour. Economics Letters, 74, 301-308. http://dx.doi.org/10.1016/S0165-1765(01)00567-5

Basu, K. (2005). Child labour and the law: Notes on Possible Pathologies. Economics Letters, 87, 169-174. http://dx.doi.org/10.1016/j.econlet.2004.10.012

Becchetti, L., \& Trovato, G. (2005). The Determinants of Child Labour: The Role of Primary Product Specialization. Labour, 19, 237-271. http://dx.doi.org/10.1111/j.1467-9914.2005.00303.x

Bhalotra, S. (2007). Is Child Work Necessary? Oxford Bulletin of Economics and Statistics, 69, 29-55. http://dx.doi.org/10.1111/j.1468-0084.2006.00435.x

Bhalotra, S., \& Heady, C. (2003). Child Farm Labour: The Wealth Paradox. World Bank Economic Review, 17, 197-227. http://dx.doi.org/10.1093/wber/lhg017

Bhat, B. A., \& Rather, T. A. (2009). Child Labour in the Handicrafts Home Industry in Kashmir: A Sociological Study. International NGO Journal, 4, 391-400.

Cigno, A., \& Rosati, F. C. (2002). Child Labour, Education, and Nutrition in Rural India. Pacific Economic Review, 7, 6583. http://dx.doi.org/10.1111/1468-0106.00150

Dammert, A. (2005). Does Child Labour Decline with Household Income? A Non-Parametric Approach. Working Paper, Syracuse, NY: Syracuse University.

Dehejia, R. H., \& Gatti, R. (2005). Child Labour: The Role of Financial Development and Income Variability across Coun- 
tries. Economic Development and Cultural Change, 53, 913-931. http://dx.doi.org/10.1086/428714

Edmonds, E., \& Pavcnik, N. (2005). The Effect of Trade Liberalization on Child Labour. Journal of International Economics, 65, 401-419. http://dx.doi.org/10.1016/j.jinteco.2004.04.001

Ersado, L. (2005). Child Labour and Schooling Decisions in Urban and Rural Areas: Comparative Evidence from Nepal, Peru, and Zimbabwe. World Development, 33, 455-480. http://dx.doi.org/10.1016/j.worlddev.2004.09.009

Forastieri, V. (2002). Children at Work: Health and Safety Risks. Geneva: ILO.

Genicot, G. (2005). Malnutrition and Child Labour. Scandinavian Journal of Economics, 107, 83-102. http://dx.doi.org/10.1111/j.1467-9442.2005.00396.x

Graitcer, P., \& Lerer, L. (1998). Child Labour and Health: Quantifying the Global Health Impacts of Child Labour. Manuscript, Washington DC: World Bank.

Hussain, M., \& Maskus, K. E. (2003). Child Labour Use and Economic Growth: An Econometric Analysis. World Economy, 26, 993-1017. http://dx.doi.org/10.1111/1467-9701.00560

Mahmood, S., Maann, A. A., Tabasam, N., \& Niazi, S. K. (2005). Socio-Economic Determinants of Child Labour in Automobile and Engineering Workshops. Journal of Agriculture \& Social Sciences, 1, 64-65.

Neumayer, E., \& de Soysa, I. (2005). Trade Openness, Foreign Direct Investment and Child Labour. World Development, 33, 43-63. http://dx.doi.org/10.1016/j.worlddev.2004.06.014

Osiruemu, E. (2007). Poverty of Parents and Child Labour in Benin City, Nigeria: A Preliminary Account of Its Nature and Implications. Journal of Social Sciences, 14, 115-121.

Parker, D. (1997). Health Effects of Child Labour. Lancet, 350, 1395-1396. http://dx.doi.org/10.1016/S0140-6736(05)65169-0

Ray, R. (2000). Analysis of Child Labour in Peru and Pakistan: A Comparative Study. Journal of Population Economics, 13, 3-19. http://dx.doi.org/10.1007/s001480050119

Rogers, C., \& Swinnerton, K. (2004). A Theory of Exploitative Child Labour. Oxford Economic Papers, 60, 20-41. http://dx.doi.org/10.1093/oep/gpm019

Shelburne, R. C. (2001). An Explanation of the International Variation in the Prevalence of Child Labour. World Economy, 24, 359-378. http://dx.doi.org/10.1111/1467-9701.00360 


\section{Appendix 1}

Q1. Demographic variables of the respondents

Age:

1) $8-11$ years
2) $12-14$ years
3) $15-17$ years

Level of education:
1) 1 - 5 class
2) 6 - 8 class
3) 9 - 10 class
4) Illiterate
Family size:

1) 4 - 6 members

2) 7 - 9 members

3) 10 - 12 members

Birth Order:
1) Eldest
2) Second
3) Third
4) Youngest

Q2. What kinds of problems you usually face during work?
1) Cuts \& burn
2) Muscle pains
3) Eyes infection
4) Orthopedic injuries

Q3. How much time do you work in a day?

Q4. Does your father alive or not?

Q5. What is the age of your father?

Q6. Do you think that old age of your father is the major reason behind your work?
1) Strongly disagree
2) Disagree
3) Uncertain
4) Agree
5) Strongly agree

Q7. Is there any disability or disease for your father is suffering from?
1) Yes
2) No

Q8. Do you think that disability or disease for which your father is suffering from impelled you to do work?
1) Strongly disagree
2) Disagree
3) Uncertain
4) Agree
5) Strongly agree 
Q9. Do you think that without your work you and your family cannot get respect and honour in your society?

1) Strongly disagree

2) Disagree

3) Uncertain

4) Agree

5) Strongly agree

Q10. You are working because your father forces you to do work?
1) Strongly disagree
2) Disagree
3) Uncertain
4) Agree
5) Strongly agree

Q11. Is it right your father is involved in criminal acts?
1) Yes
2) No
If yes than what kind of the acts he has been doing?

Q12. Do you think that such kind of criminal involvement of your father driven you to do work?
1) Strongly disagree
2) Disagree
3) Uncertain
4) Agree
5) Strongly agree 